University of South Carolina

Scholar Commons

Spring 1987

\title{
What do They Know and When do They Know it? Health Staff on the Hill
}

David Whiteman

University of South Carolina - Columbia, whiteman@sc.edu

Follow this and additional works at: https://scholarcommons.sc.edu/poli_facpub

Part of the Political Science Commons

\section{Publication Info}

Published in PS, Volume 20, Issue 2, Spring 1987, pages 221-225.

Whiteman, D. (1987). What do They Know and When do They Know it? Health Staff on the Hill. PS, 20(2), 221-225.

(C) 1987 American Political Science Association.

This Article is brought to you by the Political Science, Department of at Scholar Commons. It has been accepted for inclusion in Faculty Publications by an authorized administrator of Scholar Commons. For more information, please contact digres@mailbox.sc.edu. 


\title{
What Do They Know and When Do They Know It? Health Staff on the Hill
}

\author{
David Whiteman \\ University of South Carolina
}

\begin{abstract}
"You could tell by their blank faces that most of them had no idea what the provisions really meant." Using almost these identical words, two different congressional staff members described two separate groups: (a) the members of a congressional committee considering a Medicare reform provision at a committee mark-up and (b) the personal staff of these same members at a briefing on the provision prior to the mark-up. So what can we conclude about the level of information in Congress? Has the massive expansion of congressional information resources over the past two decades-including vast increases in the number of personal and committee staff and support agency personnel-been for naught?
\end{abstract}

During the past three years, I have been conducting a study of the approach taken by members and staff of Congress In learning about policy issues and the implications of that approach for congressional decisionmaking.' In the fall of 1984, I selected several discrete health and transportation issues which seemed likely to receive significant attention over the entire two years of the 99th Congress. My strategy was to study, for each issue, a sample of congressional "enterprises" - each made up of a member of Congress and his or her staff-as they followed and became involved in the development of the issue. ${ }^{2} \mathrm{My}$ interest was in communication about these issues both within each enterprise and among all the various enterprises. At this point, nearing the conclusion of the fieldwork, I have conducted over 300 interviews, including meeting with certain key staff members as often as six times in order to monitor their evolving understanding of the issues.

My comments in this essay will be restricted to health issues and to the role of staff. ${ }^{3}$ While the members themselves have the formal authority within Congress, many studies have demonstrated the crucial roles of staff in informing and shaping the actions of their members. ${ }^{4}$ Staff members proved to be extremely important in both of the health issues selected for study: the reform of Medicare payments to physicians (which involved the Senate Finance Committee, the House Ways and Means Committee and the House Energy and Commerce Committee) and the establishment of a

David Whiteman is an associate professor in the Department of Government and International Studies at the University of South Carolina. His primary interests are legislative decisionmaking and political communication, and he is currently working on a book tentatively entitled Does Congress Learn?

'This research was supported by grants from the National Science Foundation (SES8410769), the Dirksen Congressional Center, and the Research and Productive Scholarship Fund of the University of South Carolina.

${ }^{2}$ See Robert Salisbury and Kenneth Shepsle (1981), "U.S. Congressman as Enterprise," Legislative Studies Quarterly 6:559-576.

Interviews with members of.Congress are currently in progress.

${ }^{4}$ See Robert Zweir (1979), "The Search for Information: Specialists and Non-Specialists in the U.S. House of Representatives," Legislative Studies Quarterly 4:31-42; Louis Sandy Maise (1981), "Congressional Information Sources," in Joseph Cooper and G. Calvin Mackenzie (eds.), The House at Work (Austin: University of Texas Press), pp. 247-274); and Michael Malbin (1980), Unelected Representatives (New York: Basic Books). 
compensation system for children injured by vaccines (which involved the Senate Labor and Human Resources Committee and the House Energy and Commerce Committee).

Although the interviews with members and staff will ultimately provide the bulk of my data, I quickly realized once I began the fieldwork that a significant portion of my results would come simply from my part-time immersion in the "health policy community." Gradually I assumed a dual identity. In part I came to view myself as a political anthropologist, studying the rituals and folkways of a strange and wondrous people. ${ }^{5}$ I also came to view myself as a "lobbyist-without-a-cause," finding that I had much in common with the lobbyists that I encountered-we were outsiders always wanting to be on the inside, always wanting to be at the important committee meetings, to know what was happening behind the scenes, and to talk to the movers and shakers.

\title{
My strategy was to study, for each issue, a sample of congressional "enterprises"-each made up of a member of Congress and his or her staff-as they followed and became involved in the development of the issue.
}

\begin{abstract}
While the analysis of the data from my study is just beginning, what I can contribute at this time is the general flavor of the experience and the general character of the results, as they relate to health staff. As a reflection of the interactive nature of my experiences within the health policy community, I propose to report on some of my findings by responding to some of the more frequent questions that staff asked me during the course of my interviews.
\end{abstract}

1. "Isn't it crazy how little we know?" Asking health staff about exactly how much they know about specific health issues is a somewhat delicate task. Initial responses from personal staff, for example, are sometimes self-deprecatory - "I was hoping you wouldn't ask about that," or "why don't you ask me about an issue I know something about?" A much smaller number of staff attempted to convey a sense of omniscience - that because they were health staff they would of course know everything important about every major health issue.

Overall, a basic conclusion that can be drawn from the interviews is that, on any given issue, there are very few staff with a detailed understanding of the complexities involved. However, this conclusion must be placed in the context of what motivates staff to learn about issues in the first place. Staff are under severe time constraints and are very rational in allocating their time - if they have to learn about something, they will; if they don't, they won't. And, what determines whether or not they have to learn about something is how involved their "enterprise" is in the issue-involvement and learning are highly correlated. Only the rare staff person has the luxury to investigate areas beyond the immediate concerns of the day. Thus, to say that a particular staff member did not know very much about an issue is not at all to indict that person's capacity or level of competence. It is to say, rather, that the staff person probably had no occasion to need to know about the issue.

At a minimum, staff monitor the progress of legislative issues, tracking the issue through the committees and generally meeting with the representatives of any groups interested in presenting their perspective. This monitoring stance generally provides enough information to fulfill the basic needs of staff for writing letters to constituents

${ }^{5}$ For an extended view from this perspective, see J. Mclver Weatherford (1985), Tribes on the Hill (Hadley, Mass.: Bergin and Garvey). 
and for briefing their member for hearings, mark-ups, and floor votes. Only if a decision is made to become more significantly involved in the issue is there an incentive for staff to seek out additional information.

2. "Have you talked to the committee staff yet?" Many personal staff were quick to recommend that I talk to "the people who really know what's going on" - the committee staff. This was in accord with my expectations regarding the dispersion of knowledge about a given issue: that the further staff were removed from action on the issue, the less informed they would be. Committee staff, then, generally at the center of issue networks within Congress, would be expected to be the most informed. The personal staff of members on the relevant subcommittee would be somewhat less informed. The personal staff of other members not on the subcommittee but on the relevant full committee would be still less informed. And, the personal staff of members not on any relevant committee would be the least informed.

While this general pattern of decreasing information appears to be accurate, the knowledge (and involvement) of staff on any given issue appears to be significantly more concentrated than the pattern would imply. As expected, on the two health issues that I studied, committee staff were almost always the most informed and among the most active on the issue. What was unexpected was how quickly the level of information dropped off after that. The knowledge and involvement of most personal staff of members on the subcommittee was nowhere near that of the committee staff. In fact, some personal staff of members of the subcommittee were not significantly more informed than the staff of members not on the committee at all.

On each committee and for each particular issue, then, the most common arrangement was to have an inner core consisting of one committee staff person and perhaps two or three personal staff. Beyond this inner core, levels of information and involvement dropped off dramatically. The House and Senate vary on this point in interesting ways. In the House, the decline appears to be much more dramatic. On each issue, a very few of the personal staff become involved, and the rest simply monitor the progress of the issue, waiting for a possible mark-up. In the Senate, with larger personal staffs, the decline is much less steep. The same inner core group exists, but this drops off only gradually as the distance from the action increases. As many as half of the personal staff are reasonably involved and knowledgeable about the issue.

3. "Where did she go?" Turnover among health staff was not simply an abstract interest of mine. In order to monitor the communications networks among staff, I had developed rosters of all the committee and personal staff handling either health issue on each committee. Updating these lists became a constant occupation. On both Senate committees, for example, the committee staff member with primary responsibility for the issue being studied changed three times during the 99 th Congress. The same was true of the House Ways and Means Committee. Only the staff of the House Energy and Commerce Committee remained stable.

\section{On any given issue, there are very few staff with a detailed understanding of the complexities involved.}

Just as striking was turnover on the personal staffs. On three of the four healthrelated committees I studied, fewer than half of the members had the same staff person covering the same issue for the entire two-year period, and a few members even had three different staff covering the issue. In making my rounds with staff, one important topic became exchanging information on who had left and where they had gone-and whether or not their job was worth applying for. I would occasionally commiserate with lobbyists about the problems that turnover caused for "people like us." But aside from selfish concerns, the high rate of turnover (not necessarily of staff but of responsibility for certain issues within each enterprise) certainly has important 


\section{Health Staff on the Hill}

implications for the possibility of stable staff networks and the development and continuity of expertise over time.

4. "Have you found anyone with a health background yet?" Part of my interview schedule included a general question on the educational background and experience of the staff member, with a follow-up inquiry as to any particular background in health. With only one exception, committee staff had either advanced academic training in health issues or extensive experience. For personal staff, this question sometimes induced a fair amount of merriment. While some staff in the Senate have extensive training-including several with Ph.D.s-most personal staff have no formal background in health-related issues. ${ }^{6}$ In the House in particular, many have an undergraduate degree (most commonly in political science) and have been assigned health issues as only one of many responsibilities. An extreme, though not unique, case is the office with a single legislative assistant, for whom health issues rate one tiny slice of the entire legislative agenda.

On three of the four health-related committees I studied, fewer than half of the members had the same staff person covering the same issue for the entire two-year period.

5. "What do you think of us?" Some personal staff were so tangentially involved in health issues that they did not consider themselves to be part of any "health community." But those committee and personal staff who did consider themselves to be part of such a community often expressed curiosity about how they looked to someone from the outside.

I must say that my impressions of staff changed rather sharply during the course of the study. Initially, I was somewhat apprehensive that the fate of my project was in the hands of such an egotistical and skeptical crowd. I approached my fieldwork with a great interest in the abstract research topic and also with the knowledge that I had successfully interviewed quite a number of staff during previous projects. However, the scope of this study was somewhat intimidating, and I was concerned about my dependency on the goodwill of certain key staff-I could not afford for very many committee staff to refuse to participate.

In the end, cooperation with the study vastly exceeded my expectations. All relevant health committee staff participated in the study-one even providing a cumulative total of eight hours of interview time-as well as nearly the entire sample of personal staff. In light of this reception, I was forced to reconsider some of my preconceived notions about staff. Quite simply, the majority of these staff were friendly and helpful. How can I explain this? One alternative, of course, is to conclude that I had been coopted, that having grown dependent on these people, I had begun to identify with my "captors." Another alternative is to conclude that health staff are not the norm, that people attracted to working on health issues (as opposed to defense or tax issues) are more likely to have the welfare of fellow human beings at heart-even social scientists! Or, of course, I could conclude that most staff in general are nice people, but this is perhaps too radical a step.

6. "Why are you doing this?" Actually, a more frequent question than this one was "is this for your Ph.D.?" Either graduate students have so inundated Capitol Hill as to make this a reasonable default assumption, or staff generally could conceive of no

'See John Grupenhoff (1983), "Profile of Congressional Health Legislative Aides," The Mount Sinai Journal of Medicine 50:1. 
better reason for conducting research. Even after I indicated that I already had my Ph.D. and elaborated my reasons for conducting the study, staff sometimes remained quite puzzled as to why I was spending so much time on this project. And I must say, at relatively frequent intervals, I have been asking myself that same question.

7. "So what's the bottom line?" Two promises were made to the staff I have interviewed: I will never endanger their careers by quoting them by name, and I will send them a summary of my results - condensed into one page, of course. While I am hesitant to make any firm conclusions at this point, what I can offer is a characterization of Congress as being both extensively and unevenly informed on health issues.

At least for issues on its agenda (and this is probably a significant qualification), Congress as a collective entity appears to be extensively informed. The staff most involved in formulating policy on an issue tend to develop expertise by drawing upon a broad spectrum of relevant information-including policy analyses sponsored by congressional support agencies, executive branch agencies, and various public and private policy research organizations; expert advice provided by a host of academics, consultants, executive branch personnel, and interest group representatives; and practical and political advice from members of affected groups.

At the same time, this expertise is extremely uneven. For the vast majority of health issues, personal staff have a great appetite for basic information, but little appetite for more detailed studies. The search for more detailed information is largely reserved for the personal staff of members on health-related committees (or subcommittees, in the case of the House), and then only for perhaps one or two specific issues. Increases in the number of staff members for personal offices, therefore, may not have increased the number of general "health experts" available to members, but it does seem to have increased the number of staff who can each develop a narrow expertise on a specific issue.

This situation should perhaps not be terribly surprising, given the norm of specialization within congressional decisionmaking, particularly in the House, but I was surprised by the degree of the specialization. For example, I found it difficult to identify members, outside of subcommittee chairmen, who could be regarded as general "health specialists." In part this reflects the wealth of other distractions available to members of the committees with health jurisdiction-particularly the Senate Finance Committee and House Ways and Means and Energy and Commerce Committees. Instead, most members "specialized" in one or two particular health issues. The reputation of the House for greater specialization, then, may be, not because service in the House allows time for development of general health expertise, but simply because the House has more members, each with their narrow issue specialization.

8. "Is this like The Dance of Legislation?" Probably the clearest finding of my study is that Eric Redman lives on in the halls of Congress. ${ }^{7}$ If a staff member were to mention any political science book, it was almost always the apparently immortal Dance of Legislation. A common interpretation of staff was that I was writing a modern-day "dance book," seeking my own immortality-and perhaps some of their cooperation was based on a hope that I would carry them along with me.

'Eric Redman (1973), The Dance of Legislation (New York: Simon and Schuster). 